\title{
Temperature Effects on the Performance of Silicon Solar Cells Using PC1D
}

\author{
$1^{\text {st Rivan Muhfidin }}{ }^{1}, 2^{\text {nd }}$ Ing-Song $\mathrm{Yu}^{1}$ \\ \{isyu@gms.ndhu.edu.tw\} \\ ${ }^{1}$ Department of Materials Science and Engineering, National Dong Hwa University, Taiwan \\ ${ }^{2}$ Mechanical Engineering Department, Institut Teknologi Nasional Yogyakarta, Indonesia
}

\begin{abstract}
A photovoltaic (PV) cell is a semiconductor device that is sensitive to the temperature. The solar radiation will convert into electricity through the PV cell and the rest is converted into thermal, which raises the temperature of the PV cell. The increase in temperature on a photovoltaic cell can decrease its efficiency. The simulation of a silicon solar cell was done by PC1D software. It investigates the impact of the temperature on the performance of the solar cell, containing power maximum, open circuit voltage, and short circuit current, by the result of the PC1D. Meanwhile, fill factor and efficiency of the solar cell can be obtained from the simulation results.
\end{abstract}

Keywords: PC1D, silicon solar cell, temperature, efficiency

\section{Introduction}

Solar cell technologies are divided into three generations according to the time of the technology applied. The first generation of a solar cell is silicon-based technology, such as monocrystalline and polycrystalline silicon solar cells. The second generation of solar cells is the solar cell using thin film technology, such as CdTe, CIGS, and micromorphous silicon materials. The third generation of solar cells is more focused on the improvement of energy conversion and the light absorption coefficient of materials. Up to now, the first-generation solar cell is still widely used in the photovoltaic market.

The performance of a solar cell is compared to the other solar cell by using its efficiency. Some factors that affect solar cell efficiency are cell temperature, energy conversion efficiency, and maximum power point tracking [1]. A Photovoltaic (PV) cell is just like other semiconductor devices; it is sensitive to the temperature. The thermal model is used in predicting the temperature of the PV module [2]. It is used to know that the module temperature affects its power output. The PV panel operating temperature affects its efficiency has been described in the literature $[3,4]$. The increasing of the temperature is inversely proportional to the amount of power available.

There are several programs that can be used to simulate the solar cell, such as MATLAB, Atlas, Griddler, Quokka, and PC1D. Every software provides different parameters and results to demonstrate the solar cell close to the real conditions. PC1D is one-dimensional software that widely used for modelling crystalline solar cells. In this work, we analyze the effect of the temperature to the performance of the solar cell through its power output and the efficiency by using PC1D software.

\section{Simulations Approach}

PC1D (Personal Computer One Dimensional) is the computer program which simulates crystalline semiconductor devices. It more prefers to be used for photovoltaic devices. PC1D is 
widely used for modelling crystalline solar cells. This software was developed by the University of New South Wales, Australia. The ideal parameter for a good solar cell using PC1D has been described in the literature [5]. The various number of optimal magnitudes of emitter thickness, base thickness, emitted dopant density and base dopant density using PC1D was described in the literature [6]. It also exhibits the potential of PC1D to be widely used in solar cell design because of its efficiency and reliability. The study of the affecting power and efficiency of the monocrystalline solar cell using PC1D was done in literature [7] through different parameters. The efficiency gain at $20.35 \%$ has been achieved by the simulation with optimizing the effective parameters. Another simulation using PC1D has been also described in the literature [8-11].

From PC1D we can obtain the short circuit current $\left(\mathrm{I}_{\mathrm{SC}}\right)$, open-circuit voltage $\left(\mathrm{V}_{\mathrm{OC}}\right)$, and maximum power $\left(\mathrm{P}_{\max }\right)$. Fill factor $(\mathrm{FF})$ is the ratio of the maximum power of the solar cell divided by the open-circuit voltage $\left(\mathrm{V}_{\mathrm{OC}}\right)$ and short circuit current $\left(\mathrm{I}_{\mathrm{SC}}\right)$. The fill factor is given by this equation:

$$
F F=\frac{P_{\max }}{V_{o c} \times I_{s c}}
$$

The parameter that used to compare the solar cell is the conversion efficiency. The power conversion efficiency of a solar cell is given by this equation:

$$
\eta=\frac{V_{o c} \times I_{S c} \times F F}{P_{\text {in }}}
$$

A typical model of a silicon solar cell has been chosen on this simulation. The device schematic of the solar cell model is shown in Figure 1 and the parameter is shown in Table 1. The simulation is doing several times on different temperature as shown in Table 2.

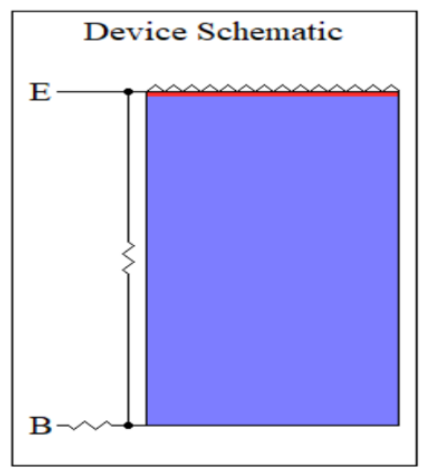

Fig. 1. Device schematic of a silicon solar cell

Table 1. Parameters of the silicon solar cell model

\begin{tabular}{cc}
\hline Parameters & Values \\
\hline Device Area & $100 \mathrm{~cm}^{2}$ \\
Front surface texture depth & $3 \mu \mathrm{m}$ \\
Exterior front reflectance & $10 \%$ \\
Emitter contact & $1 \times 10^{-6}$ \\
Base contact & $0.015 \Omega$ \\
Internal conductor & $0.3 \mathrm{~S}$ \\
Thickness & $300 \mu \mathrm{m}$ \\
Dielectric constant & 11.9 \\
Band gap & $1.124 \mathrm{eV}$ \\
\hline
\end{tabular}




\begin{tabular}{cc} 
Intrinsic concentration & $1 \times 10^{10} \mathrm{~cm}^{-3}$ \\
P-type background doping & $1.513 \times 10^{16} \mathrm{~cm}^{-3}$ \\
First front diffusion (N-type) & $2.87 \times 10^{20} \mathrm{~cm}^{-3}$ \\
Bulk recombination & $7.208 \mu \mathrm{s}$ \\
Front surface recombination & $1 \times 10^{6} \mathrm{~cm} / \mathrm{s}$ \\
Rear surface recombination & $1 \times 10^{5} \mathrm{~cm} / \mathrm{s}$ \\
\hline & \\
Table 2. Parameters of the general testing conditions \\
\hline Parameters & Values \\
\hline Temperature & $20-50^{\circ} \mathrm{C}$ \\
Constant intensity & $0.1 \mathrm{~W} \mathrm{~cm}$ \\
Spectrum & $1.5 \mathrm{~g}$ \\
\hline
\end{tabular}

\section{Result And Discussions}

The short circuit current $\left(\mathrm{I}_{\mathrm{SC}}\right)$, open-circuit voltage $\left(\mathrm{V}_{\mathrm{OC}}\right)$, and maximum power $\left(\mathrm{P}_{\max }\right)$ from the simulation can be used to calculate the fill factor and the efficiency of the solar cell. The result of the simulation of the PV cell at standard test conditions, temperature $25^{\circ} \mathrm{C}$, irradiance $1,000 \mathrm{~W} / \mathrm{m}^{2}$, and AM1.5G, shown in Figure 2. With that condition, the current $\left(\mathrm{I}_{\mathrm{SC}}\right)$ is $3.183 \mathrm{~A}$, voltage $\left(\mathrm{V}_{\mathrm{OC}}\right)$ is $0.592 \mathrm{~V}$, the power maximum is $1.362 \mathrm{~W}$ with the fill factor $(\mathrm{FF}) 0.7228$ and the efficiency $13.62 \%$.

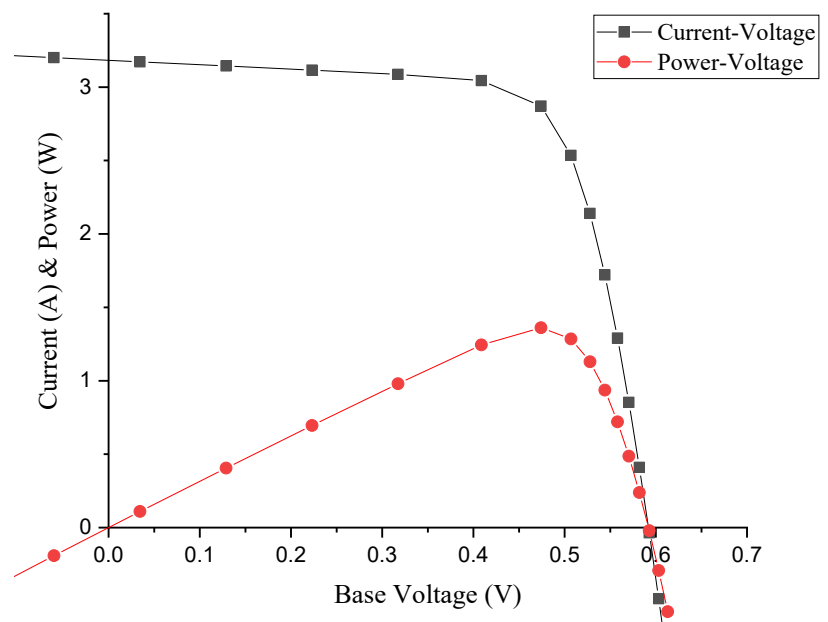

Fig. 2. Current-Voltage and Power-Voltage curves of a solar cell at $25^{\circ} \mathrm{C}$

From the simulation, we get one graphic as shown in Figure 2. We can split it into the current-voltage curve or power-voltage curve only. In this work, we apply different temperature and the result of the I-V curve shown in Figure 3. The range of the temperature is 20 to $50^{\circ} \mathrm{C}$. It is shown that the temperature affects the current and the voltage of the solar cell. It means also the fill factor and efficiency affected. The effect of the temperature on the voltage is shown in Figure 4. The voltage is inversely proportional with the temperature. Since the temperature increases, the voltage will decrease. However, the current is directly proportional to the temperature as shown in Figure 5. The temperature increase will slightly increase the current of the solar cell. This is because of the more electron-hole pairs excited in the devices. 


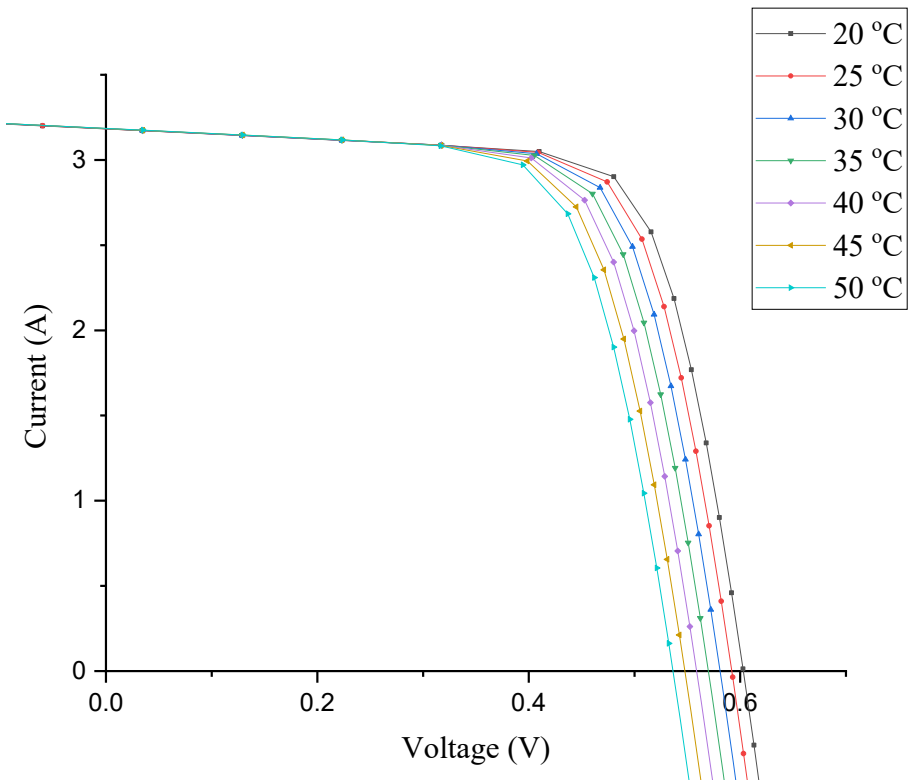

Fig. 3. I-V curves under different temperatures

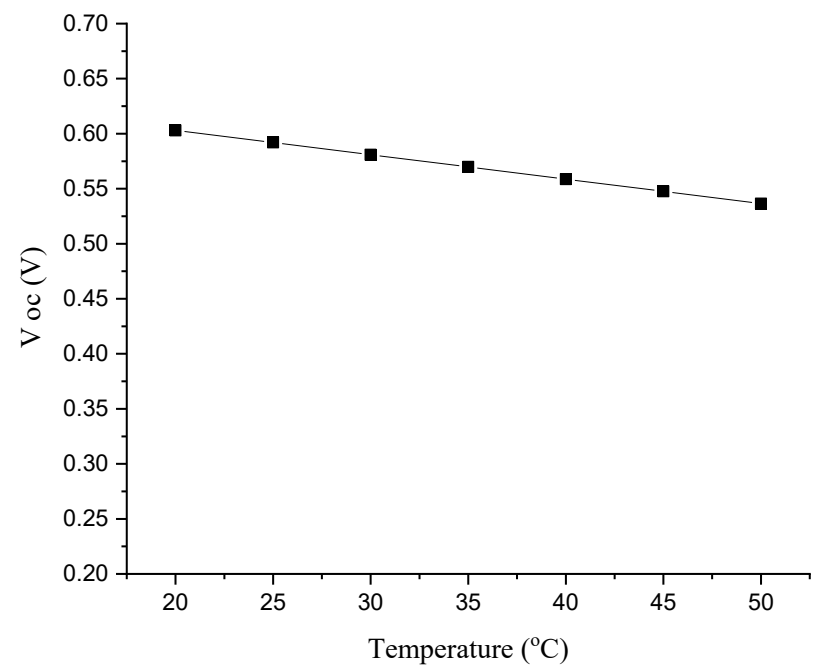

Fig. 4. Effect of temperature on voltage 


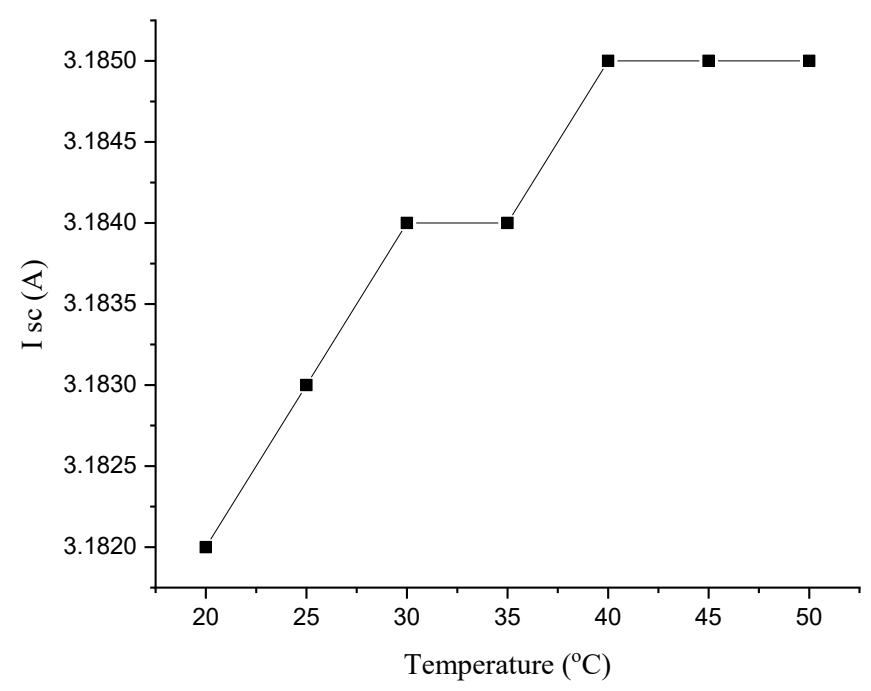

Fig. 5. Effect of temperature on current

In table 2, summarized the results of the PC1D simulation, it is more clear that temperature affects the performance of the solar cell. Since the temperature rises, the performance will decrease. It includes efficiency, fill factor, power maximum, and the open-circuit voltage. The best performance gain at $20^{\circ} \mathrm{C}$ where the efficiency is $13.98 \%$ with the fill factor (FF) 0.7286 and power maximum is $1.398 \mathrm{~W}$. The effect of the temperature is the result of an inherent characteristic of a silicon solar cell [1]. It produces a higher voltage when the temperature decreases, but it has a voltage drop at high temperature.

Table 2. Summary of the PC1D simulation

\begin{tabular}{cccccc}
\hline Temperature $\left({ }^{\circ} \mathrm{C}\right)$ & $\mathrm{I}_{\mathrm{sc}}(\mathrm{A})$ & $\mathrm{V}_{\mathrm{oc}}(\mathrm{V})$ & $\mathrm{P}_{\max }(\mathrm{W})$ & Fill Factor $(\mathrm{FF})$ & Efficiency $(\eta)$ \\
\hline 20 & 3.182 & 0.603 & 1.398 & 0.7286 & 13.98 \\
25 & 3.183 & 0.592 & 1.362 & 0.7228 & 13.62 \\
30 & 3.184 & 0.5809 & 1.326 & 0.7169 & 13.26 \\
35 & 3.184 & 0.5699 & 1.290 & 0.7109 & 12.90 \\
40 & 3.185 & 0.5587 & 1.254 & 0.7047 & 12.54 \\
45 & 3.185 & 0.5476 & 1.220 & 0.6995 & 12.20 \\
50 & 3.185 & 0.5364 & 1.186 & 0.6942 & 11.86 \\
\hline
\end{tabular}

\section{Conclusions}

In the report, the simulation of a silicon solar cell has been done by the PC1D software. The performance of the solar cell can be obtained from the equation of the conversion efficiency. The increasing temperature of silicon solar cells makes the voltage and efficiency decrease. On the other hand, the increase in temperature can slightly increase the open-circuit current of the silicon solar cell. 


\section{References}

[1] F. Dincer, M.E. Meral. Critical Factors that Affecting Efficiency of Solar Cells. Smart Grid and Renewable Energy. 2010; 1: 47-50.

[2] T.A. Olukan, M. Emziane. A Comparative Analysis PV Module Temperature Models. Energy Procedia. 2014; 62: 694-703.

[3] K.H. Hussein, I. Muta, T. Hoshino, M. Osakada. Maximum photovoltaic power tracking: An algorithm for rapidly changing atmospheric conditions. IEEE Proceedings Generation, Transmission, Distribution. 1995; 142(1): 59-64.

[4] P. Midya, P.T. Krein, R.J. Turnbull, R. Peppa, J. Kimball. Dynamic maximum power point tracker for photovoltaic applications. 27th IEEE Power Electronics Specialists Conference. 1996: 17101716.

[5] M. Belarbi, A. Benyoucef, B. Benyoucef. Simulation of the Solar Cells with PC1D, Application to Cells Based on Silicon. Advanced Energy: An International Journal. 2014; 1: 1-10.

[6] X. Cai, X. Zhou, Z. Liu, F. Jiang, Q. Yu. An in-depth analysis of the silicon solar cell key parameters optimal magnitudes using PC1D simulations. Optik. 2018; 164: 105-113.

[7] G. Hashmi, A.R. Akand, M. Hoq, H. Rahman. Study of the Enhancement of the Efficiency of the Monocrystalline Silicon Solar Cell by Optimizing Effective Parameters Using PC1D Simulation. Silicon. 2018; 10: 1653-1660.

[8] H. Haug, J. Greulich. PC1Dmod 6.2 - Improved simulation of c-Si devices with updates on the device physics and user interface. Energy Procedia. 2016; 92: 60-68.

[9] H. Haug, M.S. Wiig, R. Sondena, J. Wong. Simulating the effect of lifetime non-uniformity on solar cell performance using cmd-PC1D 6 and Griddler 2. Energy Procedia. 2016; 92: 69-74.

[10] K. Wang, I. Perez-Wurfl. A method to overcome the time step limitation of PC1D in transient excitation mode. Energy Procedia. 2014; 55: 155-160.

[11] H. Haug, A. Kimmerle, J. Greulich, A. Wolf, E.S. Marstein. Implementation of Fermi-Dirac statistics and advanced models in PC1D for precise simulations of silicon solar cells. Solar Energy Materials \& Solar Cells. 2014; 131: 30-36. 